\title{
Linking Quality Management Practices and Effective Knowledge Integration to New Product Development (NPD): An Empirical Study of Saudi-firms
}

\author{
Abdullah Mohammed Aldakhil ${ }^{1}$ \\ ${ }^{1}$ Department of Management, College of Business Administration, King Saud University, Riyadh, Kingdom of \\ Saudi Arabia \\ Correspondence: Abdullah Mohammed Aldakhil, Department of Management, College of Business Administration, \\ King Saud University, Riyadh, Kingdom of Saudi Arabia.
}

Received: December 1, 2015

Accepted: February 10, 2016

Online Published: February 17, 2016

doi:10.5430/ijfr.v7n2p1

URL: http://dx.doi.org/10.5430/ijfr.v7n2p1

The researcher would like to thank the Deanship of Scientific Research at King Saud University represented by the Research Centre in the College of Business Administration for financially supporting this research.

\begin{abstract}
This paper investigates the effects of some quality management practices (cross functional teamwork, employee participation, and reward \& recognition) and effective knowledge integration on new product development (NPD). Building upon the knowledge-based view of the firm, this paper argues that cross-functional teamwork, employee participation and reward \& recognition are three knowledge generation practices that contribute to enhance the performance of the knowledge integration capability. Knowledge integration, in turn, leads to successful new product development. This research employs structural equation modeling to empirically examine the impacts of some quality management practices on new product development, mediated by knowledge integration, using a survey data collected from 167 Saudi firms which are listed at Saudi stock exchange (Tadawul). The findings suggest that the capability of producing new products and / or services in the Saudi firms is positively affected by the cross-functional teamwork, employee participation and reward \& recognition. It is also revealed that these three practices are drivers for integration knowledge in the firms.
\end{abstract}

Keywords: quality management, knowledge integration, New Product Development (NPD), cross-functional teamwork, reward \& recognition, employee participation

\section{Introduction}

New product development is in a debate everywhere and firms are taking radical measures to improve their performances all over the globe. The prior research in this area has concentrated on numerous viewpoints, arguments and adding different factors including quality administration, operational exhibitions or budgetary execution (Molina et.al 2007). This paper unfolds another aspect of the area in order to analyze the relationship between cross-functional teamwork, reward \& recognition and employee participation as knowledge integrating factors. Managing knowledge and integrating knowledge is become a growing field in the corporate world, as it is believed that this is the area where the contemporary firms can compete each other. It is believed that the equal sizes firms have same resources like financial, structural and social resources; therefore, the difference lies with effectively managing the knowledge in the firm. Managing knowledge can also be considered as competitive advantage for the firms, which has positive effects on the business (Davenport \& Grover, 2001).

In the knowledge management process, knowledge integration has been considered as an essential component in developing new products (Lee \& Yang, 2000). Managing knowledge is a huge process through which the firms can pick up the advantages of learning and be successful (Hung et.al 2008). Knowledge integration is very important for the inter collaboration in the firms. The knowledge which is stored in the brains of employees should be integrated and applied in the development of new products. The integration of knowledge can be considered as the disguise procedure of obtained learning into critical thinking (Chen et.al 2007). Having said all this, the paper investigated the relationship between cross-functional teamwork, employee participation and reward \& recognition as the antecedents 
of knowledge integration leading towards the new product development (NPD). It is also argued that, currently the knowledge integration phenomenon is poorly understood by the Saudi firms. Therefore, this paper also addresses the theoretical gaps in the literature on knowledge integration. Furthermore, the results of this paper will support knowledge based view theory of the firms.

\section{Literature Review}

Quality management (QM) is a strategic tool to improve organizational performance. Flynn and his colleagues (1994) defined quality management as "an integrated approach to achieving and sustaining high quality output". Also quality management has been defined as an approach to management composed of a "set of mutually reinforcing principles, each of which is supported by a set of practices and techniques" (Dean and Bowen, 1994). From the pioneering works of Saraph et al. (1989), large number of studies has drawn on the literature of quality management to identify the key QM practices. Also, many studies in QM have developed measurement instruments to evaluate its implementation in the organization. Sousa and Voss (2002) demonstrated that QM includes improvement practices that influence both the firm's internal and external environments. Likewise, it includes practices focused on social parts of the firm, such as cross-functional teamwork, employee participation and recognition \& rewards. Recently, researchers have begun to relate knowledge management to quality management (Tseng, 2016). The early work in QM research used analytic models to understand the link between quality and learning. Fine (1986) investigated one of the first studies that link quality and learning. Basically he developed an analytical model that explored the relationship between failure cost and conformance cost, and discovered that the best quality level enhances over time because of learning. Wruck and Jensen $(1994,1998)$ emphasize the significance of the scientific method and the allocation of decision rights in total quality management. They argued that centralized and decentralized decision rights allocation lead to suboptimal results. As an alternative, decision rights should be allocated based upon specific knowledge of organizational workers. Specific knowledge is defined as idiosyncratic knowledge that is hard and costly to transfer. However, this paper explores the processes that lead to knowledge integration and how QM practices can support these processes. In investigating the problem-solving process at three automakers plants, MacDuffie (1997) found that problems framed as learning opportunities had a positive impact on the improvement activities. Mukherjee et al. (1998) mentioned two types of learning in QM improvement activities, first, conceptual learning (know-why) and operational learning (know-how). The literature on quality and knowledge has concentrated primarily on explicit knowledge, which tends to be simply shared and imitated. However, Dooley (2000) noticed, "since the ultimate value of the firm depends on knowledge that cannot be imitated, it is reasonable to assume that knowledge which is tacit and not easily imitated, as opposed to explicit knowledge, will grow in importance. Based on Lakhal et. al. 2006 study of QM practices, three QM practices that are expected to be significant in the process of knowledge integration. First QM practice is cross-functional teamwork which refers to "the tendency to develop tasks in a group rather than individually" (Lakhal et. al. 2006). Second, employee participation which is defined as an organizational process by which management shares impacts on decision making process with his/her subordinates, individually or group (Lakhal et. al. 2006). Third selected QM practice is recognition \& reward. The primary objectives of knowledge integration and quality management are the same create more organizational knowledge which will lead to improvements (Lakhal et. al. 2006). Several quality management researchers have considered knowledge, but they have an incomplete understanding of what knowledge integration means. Dooley (2000) suggested, the future of QM research will require a more understanding of the role of tacit knowledge. This emphasizes the importance of using knowledge frameworks that take into account tacit knowledge when understanding QM practices. Many studies have been made in the QM literature, but none of them explicitly consider both tacit and explicit knowledge. Prior research has only considered incomplete views of knowledge, often concentrating on only tacit or explicit knowledge and rarely considered the knowledge integration processes. This paper, applies the (Lakhal et. al. 2006) three factors of quality management namely, cross-functional teamwork, reward \& recognition and employee participation as the antecedents knowledge-integrating in the Saudi firms with the context of new product development. Knowledge integration can be defined as, exchanging, sharing absorbing and applying data and information (Paulin and Suneson, 2012). Knowledge integration is the undertaking of distinguishing how new and existing information cooperates while joining new data into a learning base (Wijnhoven, 1999). The knowledge clusters create the information inside the organization as well as regularly looking for outside sources. These clusters and individuals ought to join their integral information into another learning set. All together for a work gathering to be profitable, the gathering individuals ought to have their very own profound learning regions and a gratefulness for the significance of their gathering individuals' information. Both outside and inner information ought to be coordinated into gathering reactions (Anand, et.al 2003). New product development needs the use of different skills and expertise, as well as the accumulated knowledge of the firm in order to enhance the performance of the new product development. The integration of all knowledge into the business processes used by the different skilled and experienced employees has good potential to improve the new 
products' performance (Camisón, \& Villar-López, 2014). Yang (2005) defined information coordination as a major procedure by which firms pick up the advantages of learning and make upper hand, this information sharing is done between peoples. If the two workers have same knowledge then the integration is not possible, therefore the knowledge integration is only possible when workers have entirely different knowledge (Grant 1996). The knowledge-based theory (KBV) of the firm states that organizational knowledge is a resource with at least the same level of importance as capital (Grant, 1996). At present, the information incorporation marvel is inadequately comprehended both practically speaking and in the writing. Consequently, the inquiry is the manner by which firms can incorporate learning to enhance the adequacy and the proficiency (Tsai et al., 2014). By exploring the writing of information reconciliation, different authors have come to characterize learning joining as an accumulation of numerous related and random exercises from k-creation to securing, stockpiling, exchange, use and even support of information (Yang 2005). Thomke et al. (1998) revealed that, new product development venture firms ought to both gain and incorporate information in order to tackle with the issues that forestall them to achieve their objectives. Notwithstanding, a small number of studies exploring the relationship between the information administration process and new item advancement including those by Lynn et.al (1999). Taking after the asset based perspective, "learning as asset" has been extensively perceived, as it addresses the linkages between information joining and an association's execution (Carlsson, 2003). The reason for learning reconciliation related exercises in the firm is to oversee and compose the entire information procedures to convey the right data to the perfect individual at the opportune time, accordingly encouraging the procedure of the right choice making (Barthes and Tacla, 2002). Accomplishing the successful learning reconciliation requires a complete comprehension of how authoritative attributes and administration rehearses sway the improvement and the utilization of information (Collinson, 2001). Along these lines, information joining can be alluded to as distinguishing the individual and aggregate learning in a firm to bolster the association to be focused, with a capacity relating to learning exchange, information sharing, learning absorption and information application (Singh and Power, 2014). New product development (NPD) is a noteworthy and complex business process. Employee participation materializes in a situation in which employees have an impact on choices and activities identified with their employments. The employees investment is an administration (or an inward reconciliation) rehearse that is actualized in numerous firms at various levels. It is logic about how employees and their insight are imperative in constant change, learning coordination forms and hierarchical achievement. There is very famous case study of a retailer John Lewis regarding the employee participation, who introduced to offer its organization shares to its own employees according to their ranks in the organization with active employee participation (Abby Cathcart, 2013). Participation refers to have power to the employees, freedom of speech and actively involvement in the decision making processes of the origination. There are many case studies and models of employee participation exists, all these argued that employee participation will lead any origination to achieve the desirable results in terms of improving their existing markets, or creating new markets, innovating the existing products or services and developing new products or services. It is obvious that, employees are motivated when they are in a position to provide new knowledge in the organization. Furthermore, many studies have revealed about employee participation in different ways and using different indicators. For instance, firms confronting ecological instability, for example, expanding client requests and deregulation are urged to actualize an abnormal state of worker support. Firms need to work as productively and viably as could be expected under the circumstances to adapt to such ecological instability to stay aggressive in the worldwide business sector. Researchers show that employing an abnormal state of employee cooperation helps the firms and its employees to acclimate to ecological changes and work conditions which will prompt more hierarchical adaptability and adequacy. Therefore, a high level of implementing employee participation in the organization will help it to gain competitive advantage and integrate the knowledge within the organization. The recognition of rewards (tangible or intangible) is always a prime motivating factor for the origination. Jin and his colleague reconfirmed that recognition \& rewards will improve the employee morality, power, self-esteem resulting towards the improvement of organizational performance (Jin, et al, 2015). Employee recognition \& rewards are useful practices of developing a knowledge environment in the origination. The terms rewards \& recognition are different concepts, reward is tangible assets and recognition can be termed as intangible assets. Recognition can be seen as giving the employees input on what they have done right. It is about perceiving employees' exertion (e.g. sharing information), learning, and performing duties. However, the term "rewards" is related to the pay and compensation. Almost all the organizations in every sector use promotions, pay, bonuses and other kinds of intangible rewards in order to encourage the employees. The employees when start recognizing that the firm's performance is determining their rewards; they will definitely work hard and change their behaviors and attitude to be consistent with organization's strategic goals and objectives. Many studies in the recent years have recognized the role and importance of teamwork among the different divisions of the organization. This sometimes refers as cross functional teamwork and sometimes integrated teamwork. For any organization in order to compete locally or globally need the members of the team to work closely with each other. 
The very famous Hawthorne studies have provided the good example of team working. The literature also agreed that implementing cross-functional teamwork in the contemporary organizations is inevitable now a day. However, the tasks or functions performed by the team members are different from organization to organization. The innovation no doubt plays an important role in the modern business and the organizations are competing between each other on the basis of innovations where the organizations believe to develop the new products or services in order to enter in the existing or new markets.

\section{Research Model and Development of Hypotheses}

It is evident from the literature that knowledge integration plays an important role in any origination in today's contemporary world. This is the area where the firm will recognize its completive advantage and most of the firms are in process of converting its tacit knowledge into the explicit knowledge. Furthermore, new product development in any organization is highly dependent on how the organization is integrating knowledge within its boundaries. Development of new product and services in any organization are highly dependent on the various internal factors, including cross-functional teamwork, employee participation and reward \& recognition. Therefore, for the purpose of this paper, four (04) hypotheses relating to the degree of QM implementation practices to the new product development through knowledge integration are generated.

\subsection{Cross-functional Teamwork and Knowledge Integration}

Quality Management's essential task is to shape the firm into knowledge groups (Molina et.at 2007). The firm which is adopting the quality management practices is comprises of accomplishing quality objectives in a convenient way and fortifying connections both inside and outside the boundaries of the firm (Dean and Evans 1994). Organizing the firm into the knowledge features will abbreviate the correspondence chains between different departments (Hansen 2002; Collins and Smith, 2006). The present enthusiasm for group based structures reacts to the need to enhance the joining of Knowledge. The implementation of cross-functional teamwork is an important factor for the firms in order to compete in the knowledge society. However, the tasks of cross functional teams might differ from firm to firm and industry to industry. The Japanese firms are successfully implementing cross-functional teamwork in their processes and are successfully converting tacit features of knowledge into explicit knowledge leading to knowledge integration in the firms for NPD (Chuang, et al, 2016). Based on previous literature review, the first hypothesis could be as:

H1: The degree of implementation of QM cross-functional teamwork is positively related to knowledge integration.

\subsection{Employee Participation and Knowledge Integration}

Generation of knowledge in organizations occurs when employees participate in the process of problem solving and share the knowledge necessary to solve the problems. The firm can acquire the tacit knowledge which is embedded in the employees of the firm in order to develop the competitive advantage through the employee participation. In order to acquire the tacit knowledge, the best way is employee participation. The knowledge can be shared and flowed easily through the employee participation and tacit features of knowledge among different employees could be utilized and disseminated among the firm. Employee participation occurs in a firm where the environment allows the employees to participate in different decisions inside the firm. Different organizations in different contexts have implemented employees' participation in their organizations. Many firms are using structured and well defined knowledge integration systems through employees' participation to facilitate knowledge sharing (Sheng, et al, 2014). This will lead to the second hypothesis

\section{H2. The degree of implementation of QM employee participation is positively related to knowledge integration}

\subsection{Recognition \& Rewards and Knowledge Integration}

The management needs to implement an effective reward system for the employees in their origination; this includes tangible and intangible. Assuming that to every errand executed there is related a cost; every worker will attempt to amplify the net prize (Tsai, K. H., \& Hsu, T. T. 2014). The firm, then again, will attempt to amplify its net advantage capacity (i.e. advantage less the entirety of pay paid to the representatives). It is obvious that creating and managing the knowledge are the key successful factors for any organization. The knowledge can be managed in a more effective manner when employees are consistently recognized as well as rewarded for their contributions in the organization (Elizabeth, Smith 2001). Along these lines, in light of this contention, the third hypothesis is,

\section{H3: The degree of implementation of recognition \& rewards is positively related to knowledge integration}

\subsection{Knowledge Integration and NPD}

Technical knowledge or specialized information is the prime and key resource for developing the new product and innovation based firms are successfully adopting these factors. For example, the successful norm and use of tacit 
knowledge and its sharing and dissemination can help to produce attainable options and help the choice making process (Hicks et. al 2002; Alatawi, Williams, and Dwivedi, 2013). NPD is no doubt a mind boggling development process, requiring the utilization of implied and unequivocal learning so as to make and apply something that is new" (Yang, 2005). It is obvious that creating and managing the knowledge are the key successful factors for any organization. The knowledge can be managed in a more effective manner when employees are consistently recognized as well as rewarded for their contributions in the organization (Elizabeth, Smith 2001). Thus, the fourth hypothesis is,

\section{H4: There is a positive relationship between knowledge integration and NPD performance.}

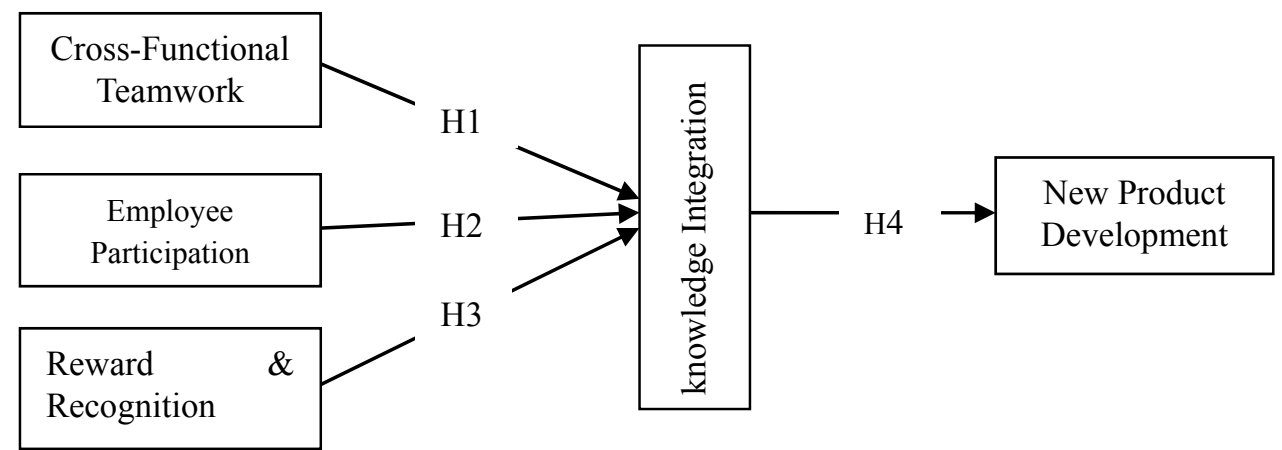

Figure 1. Proposed research model

\section{Research Methodology}

For the purpose of this paper, quantitative research methodology is adopted, so that the new product development can be measured numerically. The dependent variable (NPD) hypothesized that, it is positively associated with the number of numerous independent variables, like, Cross-functional teamwork, Employee Participation and Recognition \& Rewards with Knowledge Integration as mediating factor or variable. The dependent variable is measured through five item Likert scale measurement. The following table 1 depicts all variables included in the research along with their definitions and predicted signs as mentioned in hypothesis of these independent variables.

Table 1. Definitions and predicted signs of variables

\begin{tabular}{|c|c|c|c|}
\hline Variable & Definition & References & Sign \\
\hline $\begin{array}{l}\text { Cross-functional } \\
\text { teamwork }\end{array}$ & $\begin{array}{l}\text { The propensity to create undertakings in a } \\
\text { gathering as opposed to exclusively }\end{array}$ & $\begin{array}{l}\text { Molina et.at } 2007 \\
\text { Dean and Evans } 1994 \\
\text { Hansen } 2002 \text { Collins and } \\
\text { Smith, } 2006 .\end{array}$ & + \\
\hline $\begin{array}{l}\text { Employee } \\
\text { Participation }\end{array}$ & $\begin{array}{l}\text { Is characterized as an authoritative procedure by } \\
\text { which administration offers impacts on choice } \\
\text { making with his/her subordinates, bunch or } \\
\text { independently }\end{array}$ & $\begin{array}{l}\text { Dooley (2000) } \\
\text { Lakhal et. al. } 2006\end{array}$ & + \\
\hline $\begin{array}{l}\text { Recognition \& } \\
\text { Rewards }\end{array}$ & $\begin{array}{l}\text { The framework that connection quality change } \\
\text { endeavors with pay }\end{array}$ & $\begin{array}{l}\text { Tsai, K. H., \& Hsu, T. T. } \\
2014\end{array}$ & + \\
\hline $\begin{array}{l}\text { Knowledge } \\
\text { integration }\end{array}$ & $\begin{array}{l}\text { The procedure of exchanging learning, implicit } \\
\text { and express, crosswise over authoritative limits, } \\
\text { imparting it to people and groups at the } \\
\text { beneficiary site, absorbing and applying the } \\
\text { resultant information to take care of issues. }\end{array}$ & $\begin{array}{l}\text { Hicks et. al } 2002 \\
\text { Alatawi, Williams, and } \\
\text { Dwivedi., } 2013 \\
\text { Yang, 2005 }\end{array}$ & Mediator \\
\hline NPD performance & $\begin{array}{l}\text { Mentions to an item's effective creation, dispatch, } \\
\text { and market acknowledgment }\end{array}$ & $\begin{array}{l}\text { Dyer, 1997; } \\
\text { Osborn and Hagedoorn, } \\
\text { 1997; } \\
\text { Saxton, } 1997\end{array}$ & Relation \\
\hline
\end{tabular}




\subsection{Independent Variables}

All the independent variables, cross-functional teamwork, Employee Participation and Recognition \& Rewards are measured on a five-item Likert scale, indicating the level to which the responding firms utilize these variables/factors to operate their operations.

\subsection{Control Variables}

There are two variables which are used as control variables for this research. The firm's principal industry for example high tech, small manufacturing industry and / or service industry and the second control variable is used the number of employees. The second control variable was coded in the four categories, less than 10 employees, between 11 and 50 employees, between 51 and 100 employees and more than 100 employees.

\subsection{Data Collection and Sample}

For the purpose of this research paper, the firms operating in the Kingdom of Saudi Arabia are selected for the investigation on how cross-functional teamwork, employee participation, recognition \& rewards, knowledge integration and new product development performance effect on the firm's performance. A survey questionnaire was developed to collect data for testing the validity of the model and research hypotheses. The designed questionnaire was sent to the Saudi stock exchange (TADAWUL) listed firms operating in the Kingdom. There are 172 firms registered at the Tadawul. The variables which were included in the questionnaire were background information, cross-functional teamwork, employee participation, recognition \& rewards, knowledge integration and new product development. The questionnaire was sent to all the $167 \mathrm{firms}$, through their email addresses as well as postal addresses available at Tadawul web page. Follow-up emails, snail mails and phone calls were also made after sending the questionnaire. Of the 92 questionnaires returned as total, 12 were incomplete, either blindly filled by the respondents or incomplete. The remaining 80 were useable, complete and valid questionnaires. These 80 questionnaires were used then for the analysis; it represents a response rate $53.48 \%$. As suggested by Duncan D. Nulty (2008), the average response rate for a survey questionnaire must be more than $30 \%$ if the number of participants is ranging between 100 to 200 .

\section{Results}

This research is an attempt to measure the capability of firm to innovate a new product by using the different independent variables of quality management like teamwork, employee participation and reward \& recognition in the Kingdom of Saudi Arabia. Structural Equation Modeling (SEM) technique is used to validate the research model. It is believed that, SEM examines the spontaneous and efficient effect of three independent variables on New Product Development Capability and then the impact of these three independent variables on the knowledge integration towards new product development. Before testing the hypotheses, every one of the presumptions for SEM was analyzed. The endogenous variables all had uni-variate ordinary dispersion however displayed moderate takeoff from multivariate ordinariness. Be that as it may, Mahalanobis separations of the perceptions did not show the presence of noteworthy anomalies (outliers). Greatest probability estimation was utilized to appraise the model, according to Lie and Lomax, this assessment method is vigorous against moderate non-normality when the factors are continuous (Lie and Lomax 2005). Maximum likelihood estimation is used for the model estimation. Chi-square test is performed on the data and there is no any sign of systematic curvature in the graphs identified, therefore, all the hypotheses are tested / validated in a hierarchical way. First, direct effects of cross-functional teamwork, reward $\&$ recognition and employee participation were examined directly with new product development (See Figure 2 ). The results suggest that all the three variables Cross-functional Teamwork $(\alpha=0.22, p \leq 0.05)$, Employee Participation $(\alpha=0.20, p \leq 0.05)$ and Reward \& Recognition $(\alpha=0.18, p \leq 0.05)$ are positively related to New product Development $\left(x^{2}=6.14\right.$, d.f. $=5, x^{2} /$ d.f. $=1.22, p=0.29$, IFI $=0.95$, NNFI $=0.88$, CFI $=0.94$, RMSEA $\left.=0.05\right)$. Next, the mediator variable Knowledge Integration was added into the model (See Figure 3). All the statistical data and fit indices showed that this model fits data very well. $\left(\mathrm{x}^{2}=6.14\right.$, d.f. $=5, \mathrm{p}=0.29$, $\mathrm{x}^{2} /$ d.f. $=1.23$, IFI $=0.99, \mathrm{NNFI}=$ 0.95 , CFI $=0.98$, RMSEA $=0.05)$. All the paths from cross functional teamworking, employee participation and reward \& recognition to knowledge integration to new product development are positive and significant, which provide empirical support for Hypotheses 1, 2 and 3. In addition, knowledge integration also found to be positively related to new product development, which is consistent as expected. Total, about $40 \%$ of the variance in new product development is mentioned in the model. The proportion of variance in new product development by the model is $18 \%$. 


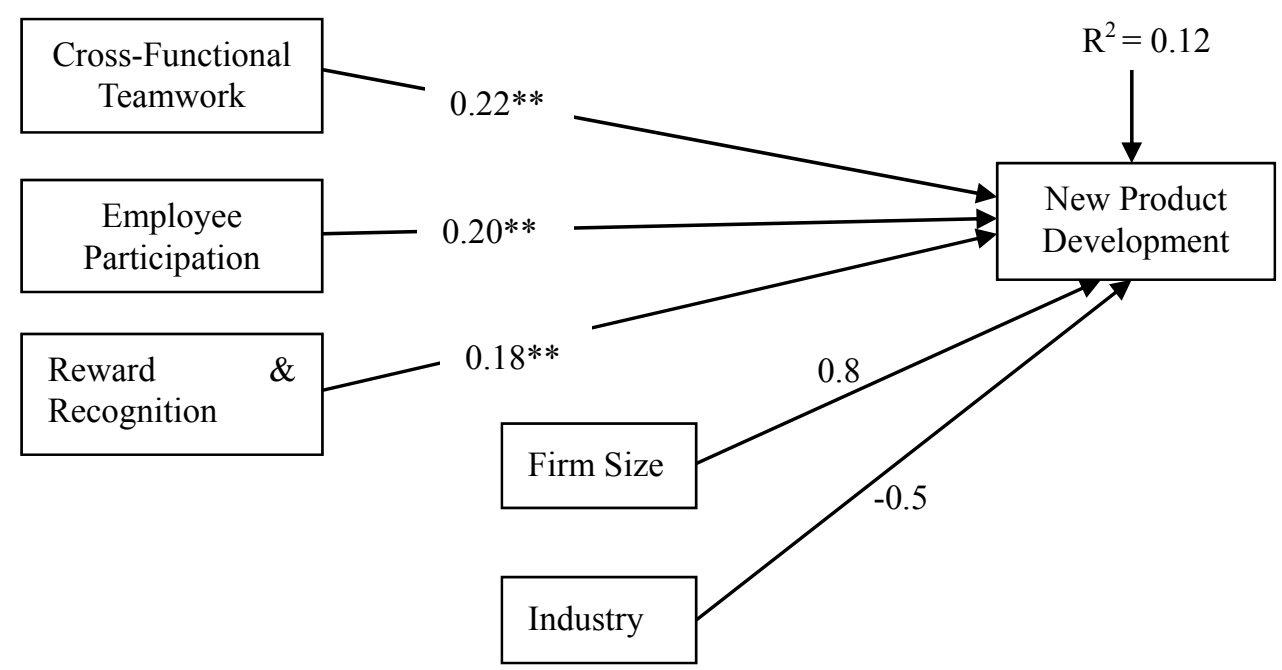

Figure 2. Direct effects of cross-functional teamwork, reward \& recognition and employee participation on NPD

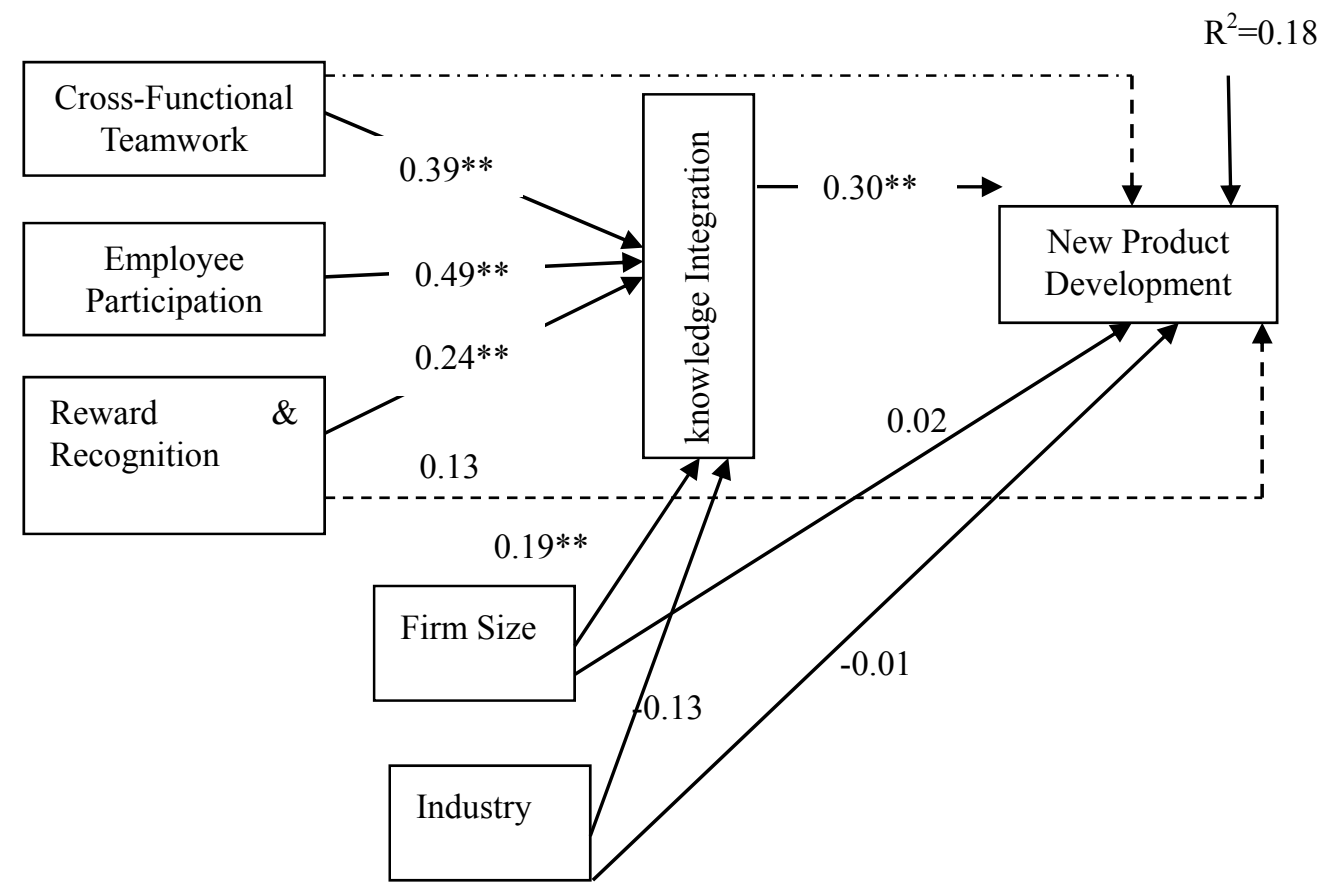

Figure 3. SEM results for the mediation model of cross-functional teamwork, reward \& recognition, employee participation, Knowledge Integration and New Product Development

\section{Discussions}

This paper has revealed that the knowledge integration plays a significant role and is positively related to all performance measures. The knowledge integration can be a powerful factor in developing new products, resulting to improve the overall performance of the firm. Moreover, the research integrates three variables mainly, cross-functional teamwork, employee participation and reward \& recognition, to understand their effects on developing the new products. The major findings and the implications can be discussed as, firstly, the results of the Structure Equation Modeling (SEM) show support for the direct effect of knowledge integration on the firms 
performance. These findings indicate that new product development is an inevitable for the firms now days specially the Saudi firms who are still immature and struggling for innovation. This valuable finding can stimulate their innovation activities and thus lead to better innovative products and / or services. Secondly, in terms of firm's knowledge integration, the paper has revealed that knowledge dissemination and utilization plays an important role in the development or innovativeness of the firm. These findings can also confirm the recognition of previous research on the importance of teamwork, employee participation and reward \& recognition for the employees. It is believed that, when Saudi firms are intent on utilizing specific knowledge for the production of new products and or services, they must recognize that knowledge integration is the best source of dissemination and utilization of knowledge that play a direct role in developing new products for the Saudi firms. The Saudi firms also need to strengthen their capability in the diffusing the knowledge effectively in their firms, through this they can then leverage the innovation for creating products and or services.

\section{Conclusions}

As the business is progressing towards the knowledge era and the societies are becoming knowledge societies because it could be argued that the firm with knowledge will be able to compete in this globalized world. In this scenario, innovations could be recognized as a successful factor for the competitive advantage for any firms specially Saudi-firms. Innovations largely depend upon the firm's performance, and then what are the important factors/variables for the Saudi firms in order to perform well in the market. This paper, however, purposely investigated the effects of teamworking, employee participation, and reward \& recognition on the development of new products which will lead the firm performance positively. The findings suggest that the firm performance of the Saudi-firms is positively affected by the factors investigated. The theoretical contributions of this paper are: first, this paper contributes to the theoretical development of an integrative model for enhancing the firm performance. Little has been done in the literature in investigating the combined effects of three constructs, including teamwork, employee participation and recognition \& rewards on the new product development leading to increase the performance of the firm. This paper, is based on extensive literature review, builds hypothesis between these constructs and the firms performance and used the case of Saudi-firms. The second contribution of this paper is the derivation of empirical support for the model's prediction. The empirical evidences of this paper prove the relationships between these constructs and the firm performance. The findings fill the gap in the literature that is lack of examining the determinants affecting the performance of the Saudi firms.

\section{References}

Abby, Cathcart. (2013). Paradoxes of participation: non-union workplace partnership in John Lewis. The International Journal of Human Resource Management, 13(1), 1-19.

Alatawi, F. M., Williams, M. D., \& Dwivedi, Y. K. (2013). Exploring Importance of Environmental Factors for Adoption of Knowledge Management Systems in Saudi Arabian Public Sector Organizations. International Journal of Electronic Government Research, 9(4), 19-37. http://dx.doi.org/10.4018/ijegr.2013100102

Anand, V., Clark, M., \& Zellmer-Bruhn, A. (2003). Team knowledge structures: Matching task to information environment. Journal of Managerial Issues, 15, 15-31.

Baer, M., \& Frese, M. (2003). Innovation in not enough: Climates for innovative and psychological safety, process innovations, and firm performance. Journal of Organizational Behavior, 24(1), 45-68. http://dx.doi.org/10.1002/job.179

Barthes, J. A., \& Tacla, C. A. (2002). Agent-supported portals and knowledge management in complex R\&D projects. Computers in Industry, 48, 3-6. http://dx.doi.org/10.1016/S0166-3615(02)00006-4

Camisón, C., \& Villar-López, A. (2014). Organizational innovation as an enabler of technological innovation capabilities and firm performance. Journal of Business Research, 67(1), 2891-2902. http://dx.doi.org/10.1016/j.jbusres.2012.06.004

Carlsson, S. A. (2003). Knowledge managing and knowledge management systems in inter-organizational networks. Knowledge and Process Management, 10(3), 194-206. http://dx.doi.org/10.1002/kpm.179

Chen, J., Tong, L., \& Ngai, E. (2007). Inter-organizational knowledge management in complex products and systems Challenges and an exploratory framework. Journal of Technology Management in China, 2(2), 134-144.

Chen, L., Ellis, S., \& Holsapple, C. (2015). Supplier Development: A Knowledge Management Perspective. Knowledge and Process Management, 22(4), 250-269. http://dx.doi.org/10.1002/kpm.1478 
Chuang, C-H., Jackson, \& S. E., \& Jiang, Y. (2016). Can Knowledge-Intensive Teamwork Be Managed? Examining the Roles of HRM Systems, Leadership, and Tacit Knowledge. Journal of Management, 42(2), 524-554. http://dx.doi.org/10.1177/0149206313478189

Collins, C. J., \& Smith, K. G. (2006). Knowledge exchange and combination: The role of human resource practices in the performance of high-technology firms. Academy of management journal, 49(3), 544-560. http://dx.doi.org/10.5465/AMJ.2006.21794671

Collinson, S. (2001). Knowledge management capabilities in R\&D: a UK-Japan company comparison. $R \& D$ Management, 31(3), 335-47. http://dx.doi.org/10.1111/1467-9310.00221

Davenport, T., \& Grover, V. (2001). Knowledge management. Journal of Management Information Systems, 18(1), 3-4.

Dayasindhu, N. (2002). Embeddedness, knowledge transfer, industry clusters and global competitiveness: A case study of the Indian software industry. Technovation, 22, 551-560. http://dx.doi.org/10.1016/S0166-4972(01)00098-0

Dean, J. W., \& Bowen, D. E. (1994). Management theory and total quality: improving research and practice through theory development. The Academy of Management Review, 19(3), 392-418.

Dooley, K. J. (2000). The paradigms of quality: evolution and revolution in the history of the discipline. Advances in the Management of Organizational Quality, 1(1), 1-28.

Dougherty, D. (1995). Managing your Core In competencies for Corporate Venturing. Entrepreneurship: Theory and Practice, 19(3), 113-136.

Dyer, J. (1997). Effective inter firm collaboration: how firms minimize transaction costs and maximize transaction value. Strategic Management Journal, 18(7), 535-548.

Elizabeth, A. S. (2001). The role of tacit and explicit knowledge in the workplace. Journal of Knowledge Management, 5(4), 311-321. http://dx.doi.org/10.1108/13673270110411733

Fine, C. H. (1986), Quality improvement and learning in productive systems. Management Science, 32(10), 13011315. http://dx.doi.org/10.1287/mnsc.32.10.1301

Flynn, B. B., Schroeder, R. G., \& Sakakibara, S. (1994). A framework for quality management research and an associated measurement instrument. Journal of Operations Management, 11(4), 339-66.

Grant, R. M. (1996). Toward a knowledge-based theory of the firm. Strategic Management Journal, 17, 109-122, Winter special issue. http://dx.doi.org/10.1002/smj.4250171110

Hansen, M. T., Nohria, N., \& et al. (2002). What's your Strategy for Managing Knowledge. Harvard Business Review, 106-116.

Hicks, B. J., Culley, S. J., Allen, R. D., \& Mullineux, G. (2002). A framework for the requirements of capturing, sorting and reusing information and knowledge in engineering design. International Journal of Information Management, 22, 263-280. http://dx.doi.org/10.1016/S0268-4012(02)00012-9

Hung, H., Kao, H., \& Chu, Y. (2008). An empirical study on knowledge integration, technology innovation and experimental practice. Expert Systems with Applications, 35, 177-186.

Kahn, K. B. (1996). Interdepartmental integration: A definition with implications for product development performance. Journal of Product Innovation Management, 13, 137-151.

Lakhal, L., Pasin, F., \& Limam, M. (2006). Quality management practices and their impact on performance. International Journal of Quality \& Reliability Management, 23(6), 625-646.

Lee, C. C., \& Yang, J. (2000). Knowledge value chain. Journal of Management Development, 19(9), $783-793$.

Lee, J-S., Back, K-J., \& Chan, Eric S. W. (2015). Quality of work life and job satisfaction among frontline hotel employees: A self-determination and need satisfaction theory approach. International Journal of Contemporary Hospitality Management, 27(5), 768-789. http://dx.doi.org/10.1108/IJCHM-11-2013-0530

Lei, M., \& Lomax, R. G. (2005). The effect of varying degrees of nonnormality in structural equation modeling. Structural Equation Modeling, 12(1), 1-27. http://dx.doi.org/10.1207/s15328007sem1201_1

Linderman, K., Schoeder, R., Zaheer, S., Liedtke, C., \& Choo, A. (2014). Integrating quality management practices with knowledge creation processes. Journal of operations management, 22, 589-607. 
Lynn, G. S., Abel, K. D., Valentine, W. S., \& Wright, R. C. (1999). Key factors in increasing speed to market and improving new product success rates. Journal of Marketing Management, 28, 319-326. http://dx.doi.org/10.1016/S0019-8501(98)00008-X

MacDuffie, J. P. (1997). The road to root cause: shop-floor problem solving at three auto assembly plants. Management Science, 43(4), 479-502. http://dx.doi.org/10.1287/mnsc.43.4.479

Molina, L., Montes, J., \& Moreno, A. (2007). Relationship between quality management practices and knowledge transfer. Journal of Operations Management, 25(3), 682-701. http://dx.doi.org/10.1016/j.jom.2006.04.007

Mukherjee, A. S., Lapre', M. A., \& Van Wassenhove, L. N. (1998). Knowledge driven quality improvement. Management Science, 44(11), S35-S49. http://dx.doi.org/10.1287/mnsc.44.11.S35

Nightingale, P. (2000). The product-process-organization relationship in complex development projects. Research Policy, 29, 913-930. http://dx.doi.org/10.1016/S0048-7333(00)00112-8

Osborn, R., \& Hagedoorn, J. (1997). The institutionalization and evolutionary dynamics of inter organizational alliances and networks. Academy of Management Journal, 40(2), 261-270. http://dx.doi.org/10.2307/256883

Oshri, I., \& Newell, S. (2005). Component sharing in complex product and systems: challenges, solutions, and practical implications. IEEE Transaction on Engineering Management, 52(4), 509-21. http://dx.doi.org/10.1109/TEM.2005.857568

Parker, H. (2000). Interfirm collaboration and the new product development process. Industrial Management and Data Systems, 100, 255-260. http://dx.doi.org/10.1108/02635570010301179

Paulin, D., \& Suneson, K. (2012). Knowledge Transfer, Knowledge Sharing and Knowledge Barriers - Three Blurry Terms in KM. The Electronic Journal of Knowledge Management, 10(1), 81-91.

Saraph, J. V., Benson, G., \& Schroeder, R. G. (1989). An instrument for measuring the critical factors of quality management. Decision Science, 20, 810-829. http://dx.doi.org/10.1111/j.1540-5915.1989.tb01421.x

Saxton, T. (1997). The effects of partner and relationship characteristics on alliance outcomes. The Academy of Management Journal, 40(2), 443-462. http://dx.doi.org/10.2307/256890

Singh, P. J., \& Power, D. (2014). Innovative knowledge sharing, supply chain integration and firm performance of Australian manufacturing firms. International Journal of Production Research, 52(21), 6416-6433.

Sousa, R., \& Voss, C. A. (2002). Quality management re-visited: a reflective review and agenda for future research. Journal of Operations Management, 20, 91-109. http://dx.doi.org/10.1016/S0272-6963(01)00088-2

Thomke, S., von Hippel, E., \& Franke, R. (1998). Modes of experimentation: An innovation process - and competitive - variable. Research Policy, 27, 315-332. http://dx.doi.org/10.1016/S0048-7333(98)00041-9

Tsai, K. H., \& Hsu, T. T. (2014). Cross-Functional collaboration, competitive intensity, knowledge integration mechanisms, and new product performance: A mediated moderation model. Industrial Marketing Management, 43(2), 293-303. http://dx.doi.org/10.1016/j.indmarman.2013.08.012

Tseng, S. M. (2016). Knowledge management capability, customer relationship management, and service quality. Journal of Enterprise Information Management, 29(2).

Wang, S., Noe, R. A., \& Wang, Z-M. (2014). Motivating Knowledge Sharing in Knowledge Management Systems: A Quasi-Field Experiment. Journal of Management, 41, 978-1009. http://dx.doi.org/10.1177/0149206311412192

Wijnhoven, F. (1999). Development scenarios for organizational memory information systems. Journal of Management Information Systems, 16, 121-147. http://dx.doi.org/10.1080/07421222.1999.11518236

Wruck, K. H., \& Jensen, M. C. (1994). Science, specific knowledge, and total quality management. Journal of Accounting \& Economics, 18(3), 247-287. http://dx.doi.org/10.1016/0165-4101(94)90023-X

Wruck, K. H., \& Jensen, M. C. (1998). The two key principles behind effective TQM programs. European Financial Management, 4(3), 401-423. http://dx.doi.org/10.1111/1468-036X.00073

Yang, J. (2005). Knowledge integration and innovation: Securing new product advantage in high technology industry. Journal of High Technology Management Research, 16, 121-135. http://dx.doi.org/10.1016/j.hitech.2005.06.007 